\title{
EXPECTATIONS IN RESPECT OF THE SUPERVISOR'S IMAGE: THE LITHUANIAN CASE
}

\author{
Odeta Merfeldaitė \\ Justinas Sadauskas \\ Mykolas Romeris University, Lithuania
}

\begin{abstract}
Each profession and the image of its representatives are being assessed taking into consideration the specifics of the activity, the environment, the existing stereotypes and the attitudes towards it. The activity of the supervisor is a new one in Lithuania therefore a lot of stereotypic attitudes appear in respect of the supervisor's profession. That means it is very important to find out what supervisor's image have the supervisors themselves, and what are the expectations of the counselled ones in respect of the professionals in this field. The goal of the research is to analyse the expectations in respect of the supervisor in Lithuania, based on insights of supervisors and of the persons with and without the experience of supervision.
\end{abstract}

Keywords: Image, image formation, supervision, supervisor.

\section{Introduction}

Lately nobody doubts any more that one of the key factors that determines the attitude of the society towards a particular institution or a profession is the image which, in its turn, associates with success and popularity. Image creation is understood as a continuous, planned activity requiring considerable resources, efforts and desire.

Every profession and the image of its representatives are being assessed taking into consideration the specifics of the activity, the environment, the existing stereotypes and the attitudes towards it (Drūteikienè \& Mackelo, 2010). The activity of the supervisor is a new one in Lithuania therefore a lot of stereotypic attitudes appear in respect of the supervisor's profession. That means it is very important to find out what supervisor's image have the supervisors themselves, and what are the expectations of the counselled ones in respect of the professionals in this field.

It should be noted that the image is gradually being created, is continuously controlled and enhanced (Uzienè, 2011; Ali-Choudhury et al., 2009), therefore it has to be improved and developed. A negative image is created when the knowledge on image formation is absent, or because of a casual attitude towards the activity being performed. Changing of the image is difficult; it requires not just a lot of efforts, but quite considerable financial resources as well. Aiming at creation of a planned professional image rather than a spontaneous one, the 
strategy of the image formation should be thought over and developed already in the beginning of the activity; it would allow the representatives of the profession to assess them in respect of the environment and to set the basic objectives of their activity (Eisenegger, 2009). The strategy of the supervisor's activity shall cover the activities by which he/she will seek for improvement of the professional image. A positive professional image secures a stable position of the supervisor in the society, the desired payment for the provided services and a better competitive position. This research attempts to answer the problem question - what factors help the formation of a positive supervisor's image.

Goal of the research is to analyse the expectations towards the supervisor's image in Lithuania.

Research methods: analysis and synthesis of scientific literature and interview.

\section{Image concept}

The conception of the image is investigated through different aspects: strategic management, personnel management, organisations, psychology, communication etc. The concept of the image comes from the Latin word "imago", which joins two meanings "imitari" (imitate) and "aemulor" (endeavour). The image is an emotional conception of goods or of a service determined by social - psychological conception (Čereška, 2004, Pranulis, et al., 2012); that means it is an impression constructed purposefully and consciously (Mikalkevičienė \& Laurinčiukienė, 2009). At first sight, it might appear that it is very simple to define the image, but, analysing scientific literature, very frequently the concept of reputation is used together with the image and/or as synonymous concepts. Analysing scientific research studies, it is possible to distinguish two schools in the image and the reputation concepts. The first school considers those concepts identical, i.e., synonymous (Alevesson, 1998; Dichter, 1985; Dowling, 1986, 1993, etc.), the other group of schools treat the concepts as different (Ali-Choudhury et al., 2009, Safon, 2009, Šontaitė \& Lydeka, 2010). In the opinion of the authors, the reputation is based on perception/understanding about an organization/person, which is formed in a course of time and is basically focussed on what the person does and what is his/her behaviour. Unlike reputation, the image is formed based on the newest beliefs. The reputation develops in a course of time, it cannot be created so fast as it can be done with the image. Even more, an organisation/a person may have good reputation (for e.g.: supplying excellent products), but have a bad image. That means that the image might be created much faster and simpler than a reliable reputation. Some scientists consider the image as a constituent part of the identity, since the identity is associated with understanding of a profession or 
an organisation, and the image is an impression of the profession or of the organisation.

Thus, the image is a picture of the profession existing in the minds of the audience - what idea comes to one's mind when hearing the name of the profession. The image may be created when the reputation must be deserved. Consequently, there is a two-sided subordination, we create the reputation ourselves, but poor reputation has influence also on the image; the same is with the image: it is tough to deserve the reputation when the image is poor. Professional reputation is based on demonstration of "high professional standards" (Cournoyer, 2008), as well as on responsible behaviour (Eisenegger, 2009). According to Eisenegger (2009), the reputation is more than functional competence, it is a moral dimension.

The image is the value of the service for an individual or for a group of individuals (Roberts, 2009). Very often the image is determined by the conception, thinking and feelings of other persons. R. Chun (2005) defines the reputation as the top of the umbrella, and the identity and the image as the constituent parts. The image is understood as the conception of the profession by the interested subjects; the identity as the self-perception of the representatives of the profession, the reputation as the picture of the inside and outside.

In other words, the image is defined as the created and formalised identity presented to the segments of external environment and forming as the result of conception process of different addressees (Lakačiauskaite, 2012). The image concept defines the whole rather than individual traits, i.e., the solid picture which is formed in human minds (Dichter, 1992).

Every supervisor, as a representative of the profession, becomes the carrier of the supervisor's image. The professional image of the supervisor may be investigated as a personal image, paying attention to the professionalism of the individual, since this phenomenon as a social-psychological phenomenon, first of all associates with human inter-relationship, conception and assessment. Scientists indicate the competence, self-confidence, stability, self-control, morality, leadership traits, optimism, adaptability, conflict solution and communication skills as assumptions for formation of positive Professional image (Drūteikienè \& Mackelo, 2010). The specialists of public relations, summarising opinions of different authors, state that the image is considered as the whole of conceptions, imagination, ideas and feelings which a person or a group of persons have in respect of a particular phenomenon or of a particular item (Uziené, 2011). The image as a specific phenomenon is named as: a condition for seeking of success and stability; as a precondition for easier access to various new possibilities (financial, people, information etc.); a guaranty of reliability and superiority in competition; as an initial contribution to the future. 
Odeta Merfeldaite, Justinas Sadauskas. Expectations in Respect of the Supervisor's Image: the Lithuanian Case

Without any doubt, defining the supervisor's image, it is possible to define it from the cognitive prospect, i.e., personal feelings in respect of the supervisor and as a communication process, which relates to the information that is spread about the supervisor.

Since the supervisor's activity is new in Lithuania, and its nature determines continuous changing and development through adapting to changing conditions of the society. Therefore it is especially important to develop a planned image, rather than a spontaneous one; it has to be thought over, and to create the image formation strategy, which would help to assess oneself in respect of the environment and to set the key goals of one's activity

\section{Discription of reserch process}

The research was carried out from September 2014 to April 2015. The research was organised in three steps. In the first step, with the purpose of highlighting of the factors that influence formation of the image, an analysis of secondary sources was performed. Scientific books and scientific magazines, internet materials were used. It should be noted that only the informational sources required for the research, guarantying reliability and well-founded were selected. Based on the information from the secondary sources, during the second step three groups of informants were surveyed.

Table 1 Characteristics of the informants (author's construction)

\begin{tabular}{|c|c|c|c|c|c|c|}
\hline \multirow[t]{2}{*}{$\begin{array}{l}\text { Item } \\
\text { No }\end{array}$} & $\begin{array}{l}\text { No supervision } \\
\text { experience }\end{array}$ & \multirow[t]{2}{*}{ Code } & $\begin{array}{l}\text { Having experience } \\
\text { of supervision }\end{array}$ & \multirow[t]{2}{*}{ Code } & Supervisors & \multirow[t]{2}{*}{ Code } \\
\hline & $\begin{array}{l}\text { Age, sex, } \\
\text { professional } \\
\text { activity area }\end{array}$ & & $\begin{array}{l}\text { Age, sex, } \\
\text { professional activity } \\
\text { area }\end{array}$ & & $\begin{array}{l}\text { Age, sex, } \\
\text { professional } \\
\text { activity area }\end{array}$ & \\
\hline 1. & $\begin{array}{l}\text { Female, 45, law } \\
\text { and order }\end{array}$ & (NS1) & $\begin{array}{l}\text { Female, } 48, \text { social } \\
\text { services }\end{array}$ & (TS1) & \multirow{7}{*}{$\begin{array}{l}\text { Sex and age of } \\
\text { the supervisors } \\
\text { is not indicated } \\
\text { securing their } \\
\text { confidentiality }\end{array}$} & (S1) \\
\hline 2. & $\begin{array}{l}\text { Female, } 56, \\
\text { education }\end{array}$ & (NS2) & $\begin{array}{l}\text { Male, 45, Head of a } \\
\text { NGO }\end{array}$ & (TS2) & & $(\mathrm{S} 2)$ \\
\hline 3. & $\begin{array}{l}\text { Male, } 43, \\
\text { management }\end{array}$ & (NS3) & Female, 45 , education & (TS3) & & (S3) \\
\hline 4. & $\begin{array}{l}\text { Female, 32, art } \\
\text { critics }\end{array}$ & (NS4) & $\begin{array}{l}\text { Male, } 40, \text { Head of a } \\
\text { NGO ( } 133 \\
\text { employees) }\end{array}$ & (TS4) & & (S4) \\
\hline 5. & $\begin{array}{l}\text { Female, } 38, \\
\text { finance }\end{array}$ & (NS5) & $\begin{array}{l}\text { Female, 50, Director } \\
\text { of a foster institution }\end{array}$ & (TS5) & & (S5) \\
\hline 6. & $\begin{array}{l}\text { Female, 39, } \\
\text { medicine }\end{array}$ & (NS6) & \multirow[t]{2}{*}{$\begin{array}{l}\text { Female, } 42 \text {, business, } \\
\text { region manager }\end{array}$} & \multirow[t]{2}{*}{ (TS6) } & & \\
\hline 7. & $\begin{array}{l}\text { Male, } 43, \\
\text { business }\end{array}$ & (NS7) & & & & \\
\hline
\end{tabular}


The scope consisted of 18 persons from different regions of Lithuania and from different groups: five supervisors, six managers that had had supervision in their organisations and seven informants that had no supervision experience (Table 1). Since the image can be divided into the visionary, the real and the desired: the visionary image - when the object is believed to have a particular image but that is not true; the real one - what others see about the person and the desired image - the image aimed at to be developed (Drūteikiené, 2007); therefore different groups of informants were selected. The number of the informants was determined following the principle of data saturation.

The informants with no experience of supervision were introduced to the concept of supervision and only after that they presented their answers. A structured interview was used for collection of research data. For the analysis of the results the content analysis method was used: 1) the texts of the respondents were read and the key aspects represented by phrases and words were distinguished, the categories were separated; 2) the nominal elements were identified; 3) the nominal elements were divided into sub-categories; 4) interpretation of the content data. A theoretical approach that the text presented by the informant is a content analysis when the material of educational diagnostic research reflects the personal reflection process as the essential aspect of experience-based learning, was followed (Žydžiūnaitė et al., 2005).

The research was performed following all principles of the ethics mandatory for research. During the research, it was attempted to make no moral, psychological or any other damage to the informants. For the purpose of the confidentiality, the informants were granted codes to secure their anonymity.

\section{Factors that influence the supervisor's image formation}

An analysis of the informants interviews confirms statements of scientists that exogenous factors and the inner characteristics of the supervisor form the image of the supervisor. Exogenous factors, such as price of the service, age, experience, looks and recommendations influence the image of the supervisor. Inner characteristics mean inner traits of the consultant and his/her posture, values, world-view, competence.

Exogenous factors. Representatives of all the three groups agreed that the price is important part of the image of a good service. The supervisors related the piece with the self-esteem of the supervisor and the value of the service for an organisation: "Price represents supervisor's evaluation of the provided services. An expensive service should be of good quality, and if the price is low, what about the quality then?" (S4); "Price is a part of the image" (S3); "a good computer, a good car costs a lot-isn't that so?" (S2); "As regards the price, I 
Odeta Merfeldaitè, Justinas Sadauskas. Expectations in Respect of the Supervisor's Image: the Lithuanian Case

believe that supervision might be undervalued very quickly, it is enough that it is underpaid." (S5).

Both informants, with and without the experience of supervision, emphasized the influence of the price on the quality of the service:

"<... I don't believe that a cheap service is attractive" (TS2); "higher price means better quality. A good supervisor cannot be bought for a low price." (NS1); "Price is important, but it should not be very low, since it brings questions about the quality" (NS5).

Both informants, with and without the experience of supervision, asserted that they, when selecting a service, would not go neither for a very high price nor for a very low one: "Market price does exist, one knows the price of consultancy" (TS5). "Price shall correspond to the price level of similar services on the market." (NS3); "...the average, neither the highest nor the lowest." (NS7);

The image of a consultant is inherent with maturity and the presence of life experience. In the opinion of the supervisors, life experience is important: "I believe that older, having life experience, supervisors are more appreciated" (S4). The informants that had supervision experience estimated the age of the supervisor as one of the criterions of reliability of the supervisor: "...age <...>in supervising directly relates with the image," (TS1); "Anyway, I would opt for a more mature age, because of bigger life experience, better organisation/ responsibility skills, ...” (TS2); “...feeling life experience, gained and /or already applied knowledge is important in communication." (TS6).

The informants that have no experience of supervision stated that they opt to choose a supervisor with life experience, middle-aged or close to the same age group: "...close to my age, since it is personal and professional experience." (NS1); "age (from 40 to 50), because experience and qualification is already present" (NS1); "the priority is over 40, it associates with the experience aspect, the maturity of a human being, and it helps in the context of relationship." (NS4).

For the informants without experience of supervision, the older age associates with categorical attitudes, and the young age - with the lack of experience: "...I would not like to go to an older supervisor, since they are very formatted and categorical (it is not the number of years, but the way of thinking is old fashioned), I would go to a younger than me one, because the vision better corresponds to the pulse" (NS2); "Very young ones cause doubts about the experience." (NS3).

According to the supervisors, the experience in supervision is an inseparable part of the supervisor's image: "Everything is linked together -..., and experience ..." (S1); "probably that is the most important thing for the image. Supervision is a profession for mature people. Experience adds to 
maturity" (S2); "Experience in supervision helps to get orders and in the initial attitude" (S3).

All those with the experience in supervision unambiguously approved that bigger experience in supervision is a reliability criterion: "It would be bloody interesting; they must have solved more than one complex dilemma." (TS4); " $<\ldots$.. > experience in supervision directly relates to the image, but for each client that buys the supervision service those elements would have a different meaning or criteria, since it is difficult to define the experience in years" (TS1).

The informants without supervision experience paid the most attention to the experience. Experience is associated with the duration (years) of supervision and its objects. Choosing a supervisor, the informants without supervision experience would inquire about the experience of the supervisor: "Duration of the work in this field is important $<. . .>$ of course, experience is important (minimum one year of practice in the field)" (NS1); "Experience in supervision is one of the most important issues, I would look for one with minimum 5 years of experience, .... I would be impressed by diversity of experience. Experience is the formation of informal skills. $<\ldots>$ It includes professional experience and the experience of informal training." <...>I would ask about the experience, what and how much experience in this field... $<\ldots>$...though I would go for someone that has experience (NS4); "Experience is the key element" (NS5); "Experience is very important" (NS3); "It is important" (NS6); "People must be strong and have experience. The person shall be a teacher to you. $<. .>$ Experience in consultancy: it is important but not critical. Experience relates to the price of the service, the less experience, the lower the price (NS7).

Both informants with experience and without it agreed that the experience of work with well-known companies is inseparable from experience: "I would like to be supervised by those that have experience of work with elite managers... <...>Anyhow, our elite manager is demanding, they will not buy anything, so this would give me some trust in him, but, most probably, he would not supervise me. But it would be bloody interesting, since they must have solved more than one complex dilemmas. <...> (TS4); "Work experience with known companies... “ (NS3); „I do care about work experience, ...experience buys me the supervisor must have seen everything from all angles, and nothing else matters for me. "(NS4);

Our appearance, especially attractiveness and constitution are significant for efficiency of communication process. It is especially important when we meet the client for the first time (Baršauskienè et al, 2007).

Clothes not just protect against negative factors of the environment but also are one of non-verbal communication signs. The importance of clothes is gradually decreasing, but this just confirms assumptions that in the initial step of 
Odeta Merfeldaite, Justinas Sadauskas. Expectations in Respect of the Supervisor's Image: the Lithuanian Case

meeting and communication, when the employees have to make as good impression as possible on the clients, clothes are very important.

According to all the supervisors, supervisor's outfit is a part of the supervisor's image related to solidness: "That is a part of the image. One must match the target group. Business most frequently buys solidness (unless knows). If they know you and want you, appearance does not matter. When talking to ministries, it is better to be more solid than in cases of business. Those would not notice you unless you wear a shirt and a jacket. Their eyes are used to that. What can we do? Disabled people. If the relationship is informal, the appearance might also be informal, sometimes even punk-style." (S2); "Visual physical image (presentable appearance (manager-level outfit rather than casual)" (S3).

According to the supervisors, the supervisor's outfit not just simplifies establishment of the contact with the client, but also presents the attitude of the supervisor towards the work and the client and it may influence the dynamics of the supervision process and forward the creation of the desired relationship: "Appearance makes the first impression and shows the attitude towards the work and the client. I believe the appearance should not upstage the clients. I think the outfit should be to some level matched to the groups of clients. <..>The outfit, in my belief, may provoke dynamics. On the other hand, a geared up supervisor may inspire with his/her set-up"(S4); "And as regards the outfit - the first meeting is very important and the outfit is not the least important; I establish a relationship through it." (S5).

Those that had the experience of supervision were less demanding towards the appearance/outfit of the supervisor. Two informants stated that the supervisor should dress neatly, since this creates business-like atmosphere: "<...> hairstyle, outfit (neat, not necessarily the smartest ones),..<...> Should be neatly dressed, of pleasant look." (TS1); "Exterior: stylish clothes, but more of the classical style rather than a fashion show. 〈...> without any doubt, the appearance at least reservedly neat, no challenging style." (TS2); "Official appearance creates business-like atmosphere. Official outfit is what I wear at work-jeans and a jacket"(TS5).

The analysis of the research data showed that in one case the exclusivity of the supervisor was assessed negatively, associating it with uncertainty or work disturbances during the course of supervision: "I would never buy supervision from a supervisor who wears earrings all over $<\ldots>$ That is an artistic person, he/she could forget the meeting. " (TS5); "Most probably I would not buy from a much sexualised girl. Because I would be afraid of my own reactions to it; it interferes with the process". (TS4);

Inner world of the supervisor. In the course of analysis of the research data, the requirements (expectations) set by the informants in respect of the 
inner world of the supervisor were highlighted. Three categories were distinguished in the requirements to the supervisor's inner world: inner characteristics of the consultant and his/her attitude, values /world-view, competence.

When assessing the attitude of the consultant, the informants stated that the supervisor should be happy, self-confident and flexible, orientated towards lifelasting learning, bravely stepping over the limits of own comfort zone and etc.: "Wisdom, personal traits, psychological immunity, creativity and etc. are important"(S1); "<...>reserved, self-confident professional who creates conditions for self-reflection and client's reflection. $<\ldots>$ self-confidence, free communication, some attributes of power, response to the needs and ability to satisfy ..." (S3); "....the image shall show that the supervisor has solved own problems, so now he/she can assist the others to solve their problems." (S2); "<... posture - ease, openness $;<\ldots>$ I believe they shall look for clients in all ways - one cannot just become a supervisor at once. So being someone else and having the supervisor's posture, you start search for customers. It is important first of all to see oneself as a supervisor and to tell the others that I am a supervisor." (S5).

In the opinion of those that have supervision experience, it is also important that the supervisor is self-confident, has inner appeal and charm, is sincere and open, and has a shuddering eyesight: "it is important that the head of supervision is self-confident" (TS3); "I believe that it is very important that the person looks and speaks with self-confidence, with sound self-confidence." (TS6); “... a straight piercing look. But not irritating." (TS6); "initial charm $<\ldots>$ the charm would add an illusion of easiness, competence, as good sales people have. So the charm... "(TS4); "Should be warm, but not too soft," (TS6).

According to those that have no experience of supervision, the behaviour of the supervisor shall represent the values that he/she is trying to pass on others; he/she must be objective, "real", open, having a sense of humour, emphatic and "represent the values that are emphasized <... >" (NS5); "Also objectivity, the format should be very flexible and broad. „Open mind", since it is a human being, not a robot" <...>personal traits (people that feel whether one works knowing the issue, or just asks because of curiosity), I would go for the one where I feel conviction; the person must have intuition, since those things bring trust; once is enough for me to know to go for or not." (NS2); "Empathy, closeness in values, <...>" (NS4); "Sense of humour <...>" (NS5); "Personal traits (ability to listen, but you see that and feel) work better than the professional ones, because supervision cannot be learned, one must have potency for that..." (NS2).

The informants that have the experience of supervision and those that do not have it defined the values/world-views that the supervisor should follow. 
Odeta Merfeldaite, Justinas Sadauskas. Expectations in Respect of the Supervisor's Image: the Lithuanian Case

According to the informants that have the experience of supervision, it is important that the supervisor trusts the capability of the client to solve his/her problem and is honest. Supervisor's choice may be influenced by the supervisor's way of work (more orientated towards psychology or management): "the supervisor believes that the "client" knows himself and can solve own problems on his/her own, that the supervisor is just a waymark, or a fingerpost. 〈...> Respect for the client is very important." (TS3); "I would buy from the one that believes that I want to and that I really need to solve the problem." (TS3); "<...>honesty from the supervisor's side could help to sell, when he/she says that you need other than this. <...> It would help me to buy it and would disclose the value position which is important" (TS4).

Both the informants with the experience and those without it agreed that the supervisor's declared world-views would influence their selection of the supervisor: " <...> it is important to estimate own position from the value point, what is the base it is built on, does it belong to any existentialist school, geshtalt, or relates his/her world-view to the Christian base. The value moment is of importance. 〈...> what is the world-view as the base for the services. I could be bought with an "existential and Christian world-view; it does not have to be worded, but that is an essential issue." (NS4); "For this the people that specialise in it are needed" (TS4).

Analysis of the research data showed how different groups of informants interpret the supervisor's competence concept. Of course, many of the requirements, provisions etc. already discussed at work include individual elements of the supervisor's competence. One of the informants stated that: " $<\ldots>$ supervisors in Lithuania would make a good impression - demonstrate their competences..." (S2); Another informant defined the supervisor's competence with the following skills: "style of speaking - inflection, vocabulary; communication - ability to establish a contact and to guide it towards relationship, listening and response to what you hear"(S5). "I believe the authenticity and development of relationship are the most important for the supervisor. <...>it is impossible to achieve trust without authenticity, <...>" (S5).

The analysis of the research data showed that those that had the experience of supervision associate the supervisor's competence with: the supervisor's experience of the work with different clients "<...> it may be disclosed through some experience, if he/she says with whom he/she has worked with." (TS4); abilities to listen, to recognise, to reflect and to explain the on-going processes: "I would buy from the one that is able not just to listen to, but also to explain the processes that are going on in the group or with me." (TS3); "<... when he said that the depth is enough - it is important for me. 〈...> I would be encouraged to buy, i.e., understanding that the person understands when I speak 
and responds to me, that is the reflection that helps me to understand already during the first dialog. 〈...> that is <...> listening and precise reflection" (TS4); " $<\ldots>$ the supervisor's competence is disclosed $<\ldots>$ through the style of speaking, which could be helping me to understand" (TS4); Insight - helps to pay attention to "something" in any told story. Concreteness. Setting points at the end of the session or at the end of discussion." (TS6); ability to control the supervision process: "Ability to communicate, to listen to, to recognise and to guide." (TS3); "Style of speaking, process control, ability to bring the process to closing and fixing of the result." (TS3); good communication skills "<...>easily communicating, communicability." (TS1); "communicative; sense of humour"; "Eye contact - as if sees through a brick wall, <...>" (TS6); " <...>created conditions for open discussion and get deep into one's problem, I knew that I personally would get as much time as required." (TS3).

According to those that had no experience of supervision, the competence of the supervisor is disclosed through: supervisor's communicative skills: "interesting lecturing, presents information in an understandable, visual way..." (NS6); "Oratorical skills, but simple language so that it is understandable to a common listener. Ability to control the audience." (NS5); "Ability to answer questions quickly and precisely." (NS5); Ability to influence the dynamics of the process: "The most influence has the one that can tear you to pieces but in the end as a conclusion you understand that you are good". (NS7); "Technical issues: to respond, to reflect and something else..." (NS2).

\section{Conclusions}

The development of a professional image is a complex process, which requires concentration and joint work of supervisors aiming at improvement of the professional image. Every profession has to select a model that fits it and develop own professional image following it.

Creating the image, it is necessary to consider: the user of the service (the needs, the social status etc.); the image of the supervisor (the looks, psychological characteristics, verbal and non-verbal language, the main activity); social behaviour in the society (social responsibility).

The social status of the user of the service supposes the choice of a particular supervisor. The heads often wish a supervisor having the experience of management. The users of the service want a supervisor of similar age. The experience of a supervisor is very important; it is understood as the experience in supervision and the objects of supervision. The look of a supervisor is a positive element of positive development of the supervisor, but the look is associated with neatness rather than with a particular outfit or its style. 
Odeta Merfeldaite, Justinas Sadauskas. Expectations in Respect of the Supervisor's Image: the Lithuanian Case

Supervisors themselves emphasize the professional development of the supervisor and professional supervision; meanwhile for the recipients of the service, the behaviour of the supervisor, which represents his/her values, certainty, openness, sense of humour, empathy, is the most important.

\section{References}

Ali-Choudhury, R. Bennett, R., \& Savani, Sh. (2009). University marketing directors` views on the components of a university brand. International Review on Public And Nonprofit Marketing, 6 (1), 13 - 27.

Alvesson, M. (1998). The Business Concept as a Symbol. International Studies of Management and Organisation, 28 (3), $100-115$.

Baršauskienė, V., \& Janulevičiūtè-Ivaškevičienè, B. (2007). Komunikacija: teorija ir praktika. Kaunas: Technologija.

Čereška, B. (2004). Reklama: teorija ir praktika. Vilnius: Homo Liber.

Chun, R. (2005). Corporate reputation: Meaning and measurement. International Journal of Management Reviews, 7(2), 91-109.

Cournoyer, B. R. (2008). TheSocial Work Skills Workbook. Thomson Brooks/Cole.

Dichter, E. (1992). What's in an image. The Journal of product and brand management, 11 (2).

Dichter, E. (1985). What's in an Image? Journal of Consumer Marketing, 2, 78-79.

Dowling, G. (1993). Developing Your Corporate Image Into a Corporate Asset. Long Range Planning, 26 (2), 105-109.

Drūteikienè, G. (2007). Organizacijos įvaizdžio valdymas, Vilnius: Vilniaus universiteto leidykla.

Drūteikienè, G., \& Mackelo, O.(2010). Dėstytojo įvaizdis ir jo ittaka studijų kokybei suvokti. Informacijos mokslai, 52, 68-83.

Eisenegger, M. (2009). Trust and Reputation in the Age of Globalisation' in Joachim Klewes and Robert Wre-schniok (eds.) Reputation Capital: Building and Maintaining Trust in the 21st Century. London: Springer Verlag.

Lakačiauskaitè, S. (2012). Organizacijos komunikacija: ̨̇vaizdžio formavimas semiotinès komunikacijos būdu. Santalka: Filosofija, Komunikacija, 20 (2), 171-179.

Mikalkevičienè, D., \& Laurinčiukienè, L. (2009). Mokomès kurti jvaizdị.verslo praktinio mokymo firmu patirtis: mokomoji metodine medžiaga. Vilnius : "Simulith" centras

Pranulis, V., Pajuodis A., Urbanavičius, S., \& Virvilaite, R. (2012). Marketingas. Vilnius: Garnelis.

Safon, V. (2009). Measuring the Reputation of Top US Business Schools: A MIMIC Modeling Approach. Corporate Reputation Review, 12 (3), 204-211.

Šontaite, M., \& Lydeka, Z. (2010). Aukštuju mokyklų korporatyvinè reputacija: formuojančiu rodiklių vertinimas. Organizaciju vadyba: sisteminiai tyrimai, (56), 92-99.

Uziené, R. (2011). Ryšiai su visuomene: ivvadas i studijas, Klaipeda.

Žydžiūnaitè, V., Merkys, G., \& Jonušaitè, S. (2005). Socialinio pedagogo profesinès adaptacijos kokybinè diagnostika. Pedagogika, 76, 23-32. 